\title{
Aplikasi Pengelolaan Perpustakaan \\ Di Smpn 1 Cibeber
}

\author{
Fietri Setiawati Sulaeman ${ }^{1}$, Muchamad Rijal Abdul Ajid ${ }^{2}$ \\ Program Studi Teknik Informatika \\ Fakultas Teknik Universitas Suryakancana \\ fietrisetiawati@gmail.com ${ }^{1}$,muchamadrijal@gmail.com²
}

\begin{abstract}
Abstrak
Perpustakaan SMPN 1 Cibeber merupakan unit penyedia fasilitas pengadaan dan peminjaman buku. Dalam pelaksanaan tugas pokoknya, terdapat kegiatan yaitu pendataan daftar buku, peminjaman dan pengembalian buku serta pembuatan laporan yang berfungsi untuk memeriksa ataupun memberikan dasar pertimbangan dalam penyusunan pengeloloaan perpustakaan pada periode selanjutnya.

Pada saat ini dalam melakukan kegiatan pengelolaan perpustakaan masih menggunakan cara manual dengan penggunaan buku dan kertas sebagai media penyimpanan data. Hal itu menyebabkan masalah diantaranya proses pencarian data yang lama, duplikasi pengolahan data serta masih manualnya proses pengecekan jumlah buku yang dipinjam.

Dalam pembuatan perangkat lunak ini menggunakan paradigma model waterfall dengan UML (unified modeling language) sebagai alat yang digunakan untuk merancang yaitu usecase diagram, activity diagram, class diagram, state diagram dan sequence diagram. Bahasa Pemrograman yang digunakan adalah Object Pascal dengan menggunakan IDE Delphi XE 10 dan MySQL sebagai DBMS.

Hasil dari perancangan dan penelitian ini diimplementasikan menjadi perangkat lunak pengelolaan perpustakaan yang membuat proses pengelolaan data, pengecekan serta pelaporan kegiatan pengelolaan perpustakaan menjadi lebih cepat, efektif dan efisien.
\end{abstract}

Kata Kunci: Aplikasi, Pengelolaan, Perpustakaan, Buku.

\section{Pendahuluan}

SMPN 1 Cibeber merupakan salah satu pelaksana pendidikan di daerah Kecamatan Cibeber Kabupaten Cianjur yang terkoordinasi langsung dengan dinas pendidikan. Fasilitas yang disediakan oleh SMPN 1 Cibeber sudah sangat memadai dari mulai ruang belajar mengajar, ruang guru, ruang TU, ruang Laboratorium, kamar mandi siswa, koperasi, lapangan olahraga, dan yang tidak kalah penting adalah ruang perpustakaan, dimana siswa dapat membaca dan meminjam buku-buku pelajaran baik yang berkaitan dengan pendidikan maupun ilmu pengetahuan lain, serta buku-buku novel dan komik yang bisa menjadi bahan pembelajaran sekaligus hiburan oleh siswa dan siswi SMPN 1 Cibeber.

Pada saat ini di perpusttakaan SMPN 1 Cibeber melakukan pencatatan peminjaman dan pengembalian buku dengan metode pencatatan pada buku besar perpustakaan dimana metode yang dipakai ini membutuhkan waktu yang sangat lama dan hal ini mengakibatkan sulitnya melakukan pengecekan daftar buku yang tersedia, karena data buku yang direkap masih bersifat sembarang, sehingga berpotensi terjadi kesalahan dalam kegiatan peminjaman dan pengembalian buku yang ada di perpustakaan. Dan hal ini menyebabkan proses pengelolaan yang tidak efektif dan efisien apabila data yang diolah jumlahnya besar.

\section{Tujuan}

Tujuan yang akan dicapai dari penelitian ini adalah:

a. Mempermudah dalam proses peminjaman dan pengembalian buku perpustakaan.

b. Mempermudah dalam pembuatan laporan daftar buku dan transaksi peminjaman.

c. Mempermudah pengecekan keterlambatan pengembalian buku beserta jumlah sanksi yang diberikan.

\section{Batasan Masalah}

Untuk pembuatan aplikasi pengelolaan perpustakaan ini berjalan terarah dan pembahasan tidak terlalu luas, maka batasan masalah yang dibahas adalah :

a. Pengecekan daftar buku di perpustakaan.

b. Pengecekan denda apabila siswa terlambat mengembalikan buku.

c. Pendataan siswa yang meminjam maupun mengembalikan buku di perpustakaan.

d. Pembuatan laporan daftar buku dan transaksi peminjaman buku.

e. Tidak membahas pengelolaan data siswa 


\section{Landasan Teori}

\subsection{Perpustakaan}

Perpustakaan adalah suatu unit kerja dari satu badan atau lembaga tertentu yang mengelola bahan-bahan pustaka, baik berupa buku-buku maupun bukan berupa buku (non book material) yang diatur secara sistematis menurut aturan tertentu sehingga dapat digunakan sebagai sumber informasi oleh pemakainya (Ibrahim Bafadal, 2001: 23)

\subsection{Pengelolaan}

Beberapa definisi pengelolaan:

a. Prajudi Atmosudirdjo (1982), pengelolaan adalah kegiatan pemanfaatan dan pengendalian atas semua sunber daya yang diperlukan untuk mencapai tujuan tertentu.

b. Sondang P. Siagian (1997), pengelolaan adalah soft skill atau keterampilan untuk mencapai suatu hasil tertentu dengan menggunakan tenaga atau bantuan orang lain.

Berdasarkan definisi tersebut dapat disimpulkan bahwa pengelolaaan adalah suatau kegiatan pemanfaatn dan pengendalian atas sumber daya berupa soft skill atau keterampilan untuk suatu tujuan tertentu.

\subsection{Aplikasi}

Ada beberapa definisi aplikasi:

a. Supriyanto (2005: 29), Aplikasi adalah program yang memiliki aktifitas pemrosesan perintah yang diperlukan untuk melaksanakan permintaan pengguna dengan tujuan tertentu.

b. Jogiyanto (1990: 110), Aplikasi merupakan penggunaan dalam suatu komputer, instruksi atau pernyataan yang disusun sedemikian rupa sehingga komputer dapat memproses input menjadi output.

c. Hendrayudi (2009: 71), Aplikasi adalah kumpulan perintah program yang dibuat untuk melakukan pekerjaan-pekerjaan tertentu.

Berdasarkan berbagai definisi tesebut, dapat disimpulkan bahwa aplikasi adalah program siap pakai yang dapat digunakan untuk menjalankan perintah-perintah dari pengguna aplikasi tersebut dengan tujuan mendapatkan hasil yang lebih akurat sesuai dengan tujuan pembuatan aplikasi tersebut.

\section{Analisis Sistem}

\subsection{Analisis Masalah}

Dalam pengelolaan perpustakaan, kegiatan peminjaman dan pengembalian serta pengecekan buku merupakan kegiatan utama yang biasa dilakukan. Pada kegiatan peminjaman dan pengembalian buku, admin harus selalu cepat dan akurat. Namun, karena keterbatasan pegawai ataupun kemahiran mengakibatkan munculnya kendala ketidakakuratan dan keterlambatan pendataan serta pengecekan buku. Belum lagi terjadinya data yang hilang atau kartu pinjam yang hilang. Hal itu akan menyulitkan admin dalam memasukan data, karena tidak adanya data sumber dari kartu pinjam tersebut dan siswa pun tidak dapat meminjam buku karena kartu pinjam adalah syarat dalam peminjaman buku di perpustakaan. Sehingga kegiatan pengelolaan perpustakaan belum efektif dan efisien.

Dengan aplikasi pengelolaan perpustakaan di SMPN 1 Cibeber ini diharapkan dapat membantu admin dalam hal pendataan peminjaman dan pengembalian serta pengelolaan perpustakaan yang lainnya sehingga kegiatan perpustakaan menjadi lebih efektif dan efisien.

\subsection{Analisis Prosedur}

Prosedur adalah proses kegiatan yang dikerjakan dan terdiri dari tahapan-tahapan, siapa yang mengerjakan proses, dan bagaimana suatu proses dikerjakan. Berikut adalah prosedur yang sedang berjalan pada aplikasi pengelolaan perpustakaan:

a. Siswa mencari buku yang akan dipinjam dari perpustakaan minimal 1 buku yang akan dipinjam.

b. Siswa melaporkan peminjaman kepada admin dengan membawa kartu perpustakaan sebagai syarat peminjaman buku.

c. Admin akan mencatatkan kode buku, judul buku, tanggal peminjaman, tanggal pengembalian pada kartu perpustakaan milik siswa yang akan disimpan diperpustakaan.

d. Admin akan menulis tanggal peminjaman dan tanggal pengembalian (maksimal 3 hari dari hari peminjaman) pada kertas yang ada dibuku sebagai catatan pengingat untuk siswa yang meminjam buku.

e. Ketika siswa akan mengembalikan buku, maka siswa diwajibkan membawa buku yang dipinjam lalu melaporkan pengembalian buku kepada admin untuk diproses pendataan pengembalian buku

f. Admin akan mengecek tanggal peminjaman dan tanggal pengembalian pada kertas yang ada pada buku, jika pengembalian melewati dari batas yang ditentukan maka siswa akan dikenakan sanksi dengan membayar uang sebesar 500 rupiah per telatnya hari dari tanggal pengembalian.

g. Apabila pencatatan semua data pengembalian telah selesai, maka admin akan mengembalikan kartu perpustakaan milik siswa yang disimpan di perpustakaan

h. Admin menuliskan semua data peminjaman dan data pengembalian pada buku harian perpustakaan sebagai bahan laporan.

i. Laporan akan diberikan kepada kepala sekolah untuk ditinjau.

\subsection{Analisis Fungsional}

Analisis fungsional menggambarkan fungsional atau layanan sistem. Berikut analisis fungsional atau modul yang dibutuhkan oleh sistem yang nantinya akan digunakan oleh user pada aplikasi pengelolaan perpustakaan:

a. Fungsi login atau akses masuk ke sistem

$b$. Fungsi halaman utama $a d m i n$

c. Fungsi pembuatan daftar buku

d. Fungsi pengelolaan transaksi

e. Fungsi pengelolaan laporan

$f$. Fungsi pengaturan akun admin

$g$. Fungsi logout 


\subsection{Analisis Non-Fungsional}

Analisis kebutuhan non-fungsional menggambarkan kebutuhan diluar sistem yang diperlukan untuk menjalankan aplikasi yang dibangun. Adapun kebutuhan non-fungsional untuk menjalankan aplikasi pengelolaan perpustakaan meliputi kebutuhan perangkat keras, kebutuhan perangkat lunak, dan pengguna yang akan menggunakan sistem.

\section{Analisis Perancangan}

\subsection{Scenario-Based Modeling \\ 6.1.1 Aktor}

Aktor merupakan representasi orang atau perangkat yang menggunakan sistem dan memiliki sifat serta fungsi yang dijelaskan dalam sebuah kontek yang memiliki peran terhadap sistem.

Tabel 1 Penjelasan Aktor pada Use case

\begin{tabular}{|l|l|}
\hline \multicolumn{1}{|c|}{ Aktor } & \multicolumn{1}{c|}{ Keterangan } \\
\hline Admin & $\begin{array}{l}\text { Orang yang mengelola } \\
\text { data perpustakaan }\end{array}$ \\
\hline
\end{tabular}

\subsubsection{Use Case}

Use case merepresentasikan cara yang dilakukan aktor melalui fungsi dari awal dari akhir

Tabel 2 Penjelasan Use Case

\begin{tabular}{|c|c|c|}
\hline Kode & $\begin{array}{l}\text { Sistem Use } \\
\text { Case }\end{array}$ & Keterangan \\
\hline U1 & Login & $\begin{array}{lr}\text { Admin } & \text { sistem } \\
\text { memasukan } & \text { username } \\
\text { dan password } & \text { untuk } \\
\text { masuk } & \text { kedalam } \\
\text { sistem.Apabila } & \text { admin } \\
\text { lupa akun login makan } & \text { dapat } \\
\text { admin } & \text { fasilitas } \\
\text { menggunakan dan } \\
\begin{array}{l}\text { lupa username } \\
\text { password. }\end{array}\end{array}$ \\
\hline $\mathrm{U} 2$ & $\begin{array}{l}\text { Halaman Utama } \\
\text { Admin }\end{array}$ & $\begin{array}{l}\text { Setelah log in admin } \\
\text { sistem dapat melihat } \\
\text { halaman utama admin. }\end{array}$ \\
\hline U3 & Daftar Buku & $\begin{array}{l}\text { Admin sistem dapat } \\
\text { mengelola semua buku } \\
\text { yang ada diperpustakaan. }\end{array}$ \\
\hline U4 & $\begin{array}{l}\text { Pengelolaan } \\
\text { Transaksi }\end{array}$ & $\begin{array}{l}\text { Admin sistem dapat } \\
\text { mengelola peminjaman } \\
\text { dan pengembalian siswa } \\
\text { serta dapat melihat } \\
\text { besarnya denda sangsi } \\
\text { yang diberikan apabila } \\
\text { waktu pengembalian } \\
\text { melewati batas hari yang } \\
\text { ditentukan. }\end{array}$ \\
\hline U5 & $\begin{array}{l}\text { Pengelolaan } \\
\text { Laporan }\end{array}$ & $\begin{array}{lc}\text { Admin } & \text { sistem dapat } \\
\text { melihat laporan } & \text { daftar } \\
\text { buku dan transaksi. } & \end{array}$ \\
\hline U6 & $\begin{array}{l}\text { Pengaturan } \\
\text { Akun Admin }\end{array}$ & $\begin{array}{l}\text { Admin sistem dapat } \\
\text { mengatur akun admin. }\end{array}$ \\
\hline $\mathrm{U} 7$ & Logout & Admin $\quad$ sistem dapat \\
\hline
\end{tabular}

\begin{tabular}{|l|l|l|}
\hline & $\begin{array}{l}\text { keluar dari halaman } \\
\text { utama admin. }\end{array}$ \\
\hline
\end{tabular}

\subsubsection{Use Case Diagram}

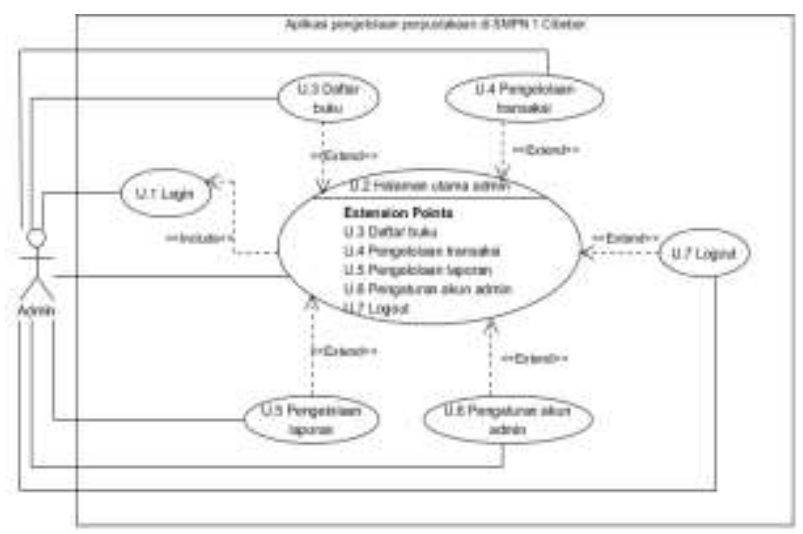

\section{Gambar 1 Use Case Diagram Aplikasi Pengelolaan Perpustakaan}

\subsection{Class Based-Modeling 6.2.1 Class Diagram}

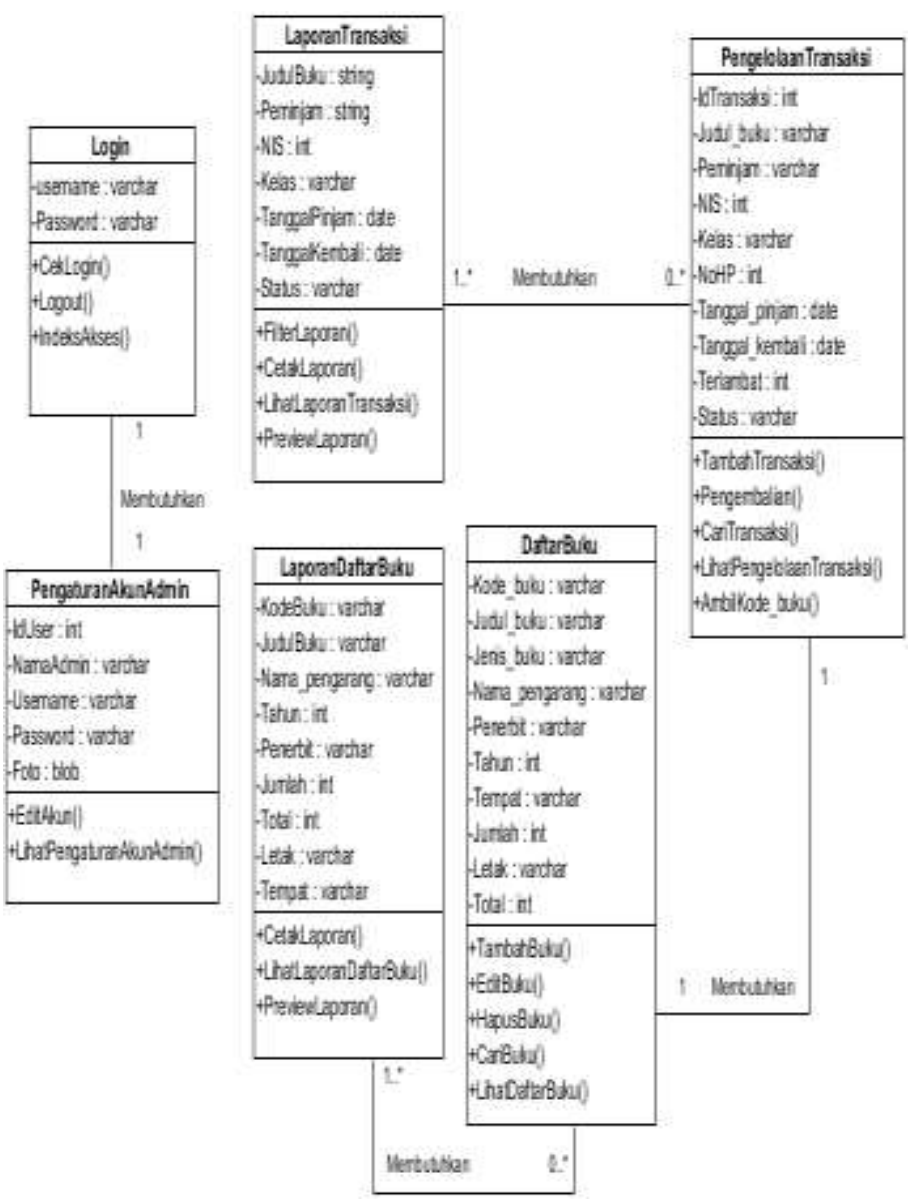

Gambar 2 Class Diagram Aplikasi Pengelolaan

6.3 behavioral Modeling Perpustakaan

\subsubsection{State Diagram}




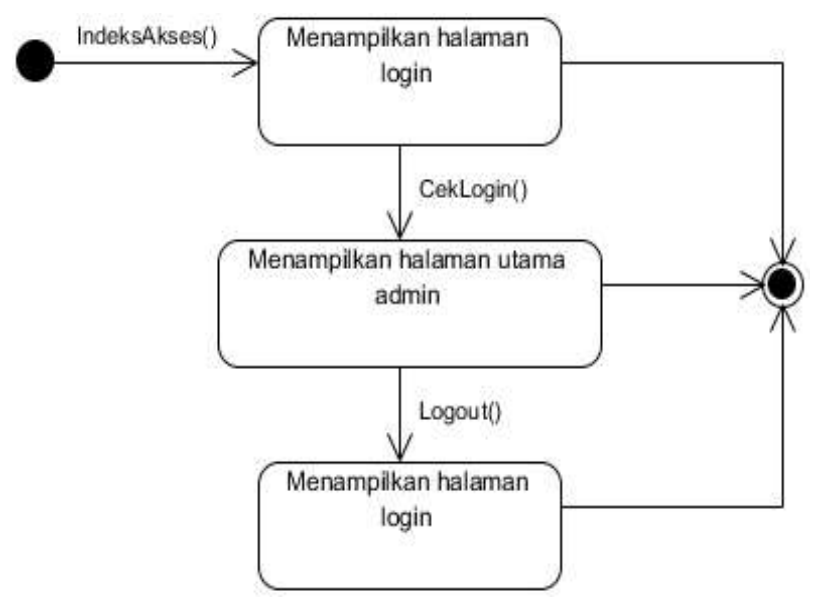

Gambar 3 State Diagram Login

Keterangan:

Pada state diagran login Terdapat tiga fungsi ketika sistem mengakses objek Login. Fungsi tersebut memicu sistem untuk melakukan event sesuai dengan fungsi yang telah dijalankan.

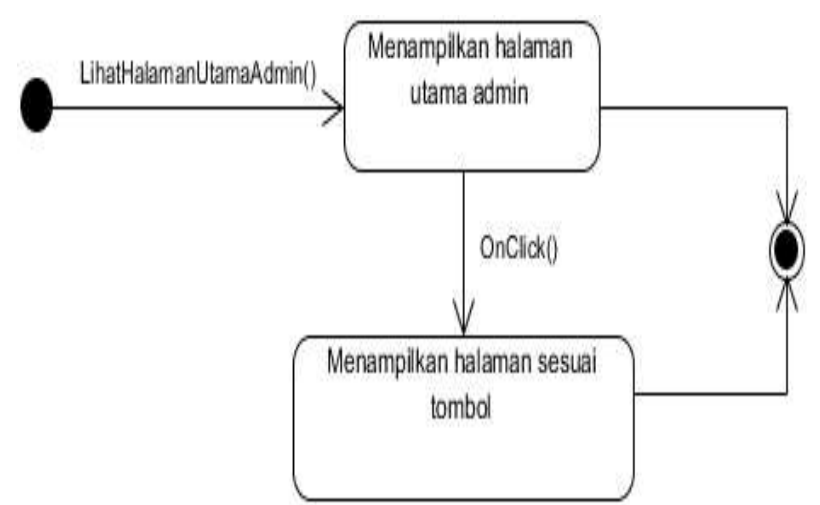

Gambar 4 State Diagram Halaman Utama Admin

Keterangan:

Pada state diagram halaman utama admin terdapat satu fungsi ketika sistem mengakses objek halaman utama admin. Fungsi tersebut memicu sistem untuk melakukan event sesuai dengan fungsi yang telah dijalankan.

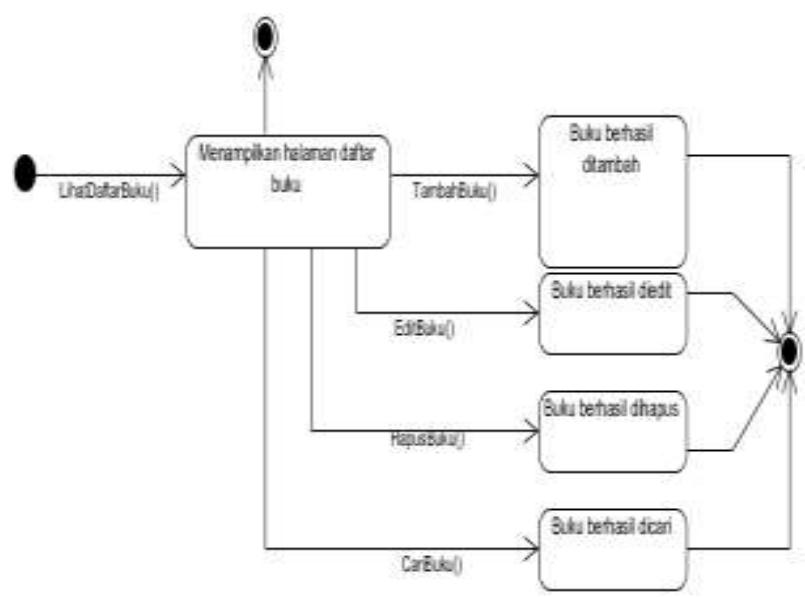

Gambar 5 State Diagram Daftar Buku
Pada state diiagram daftar buku terdapat lima fungsi ketika sistem mengakses objek daftar buku. Fungsi tersebut memicu sistem untuk melakukan event sesuai dengan fungsi yang telah dijalankan.

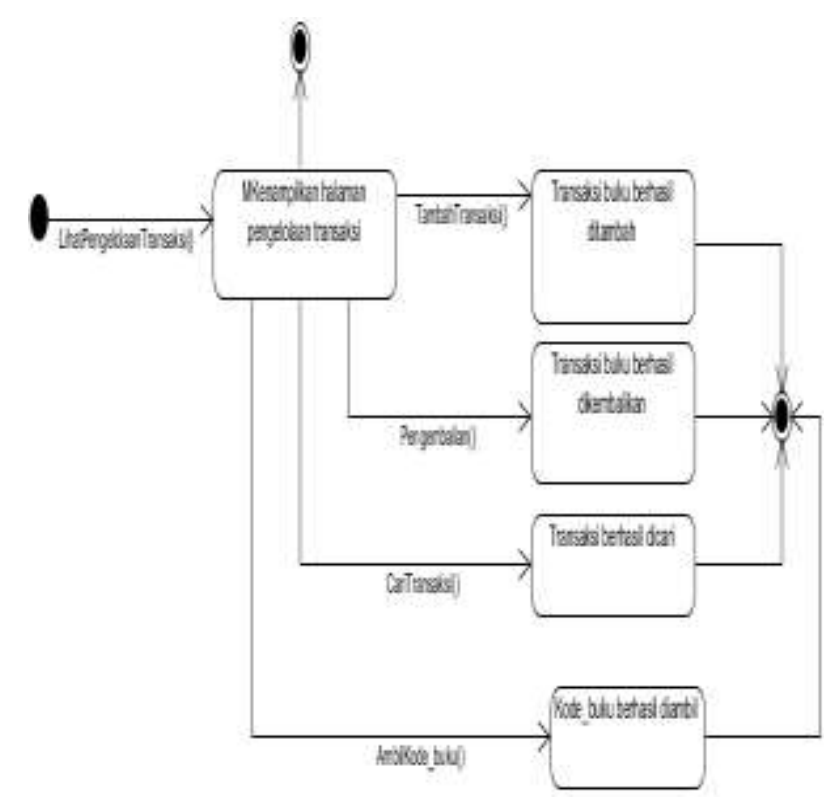

\section{Gambar 6 State Diagram Pengelolaan Transaksi}

Keterangan:

Pada state diagram pengelolaan transaksi terdapat lima fungsi ketika sistem mengakses objek pengelolaan transaksi. Fungsi tersebut memicu sistem untuk melakukan event sesuai dengan fungsi yang telah dijalankan.

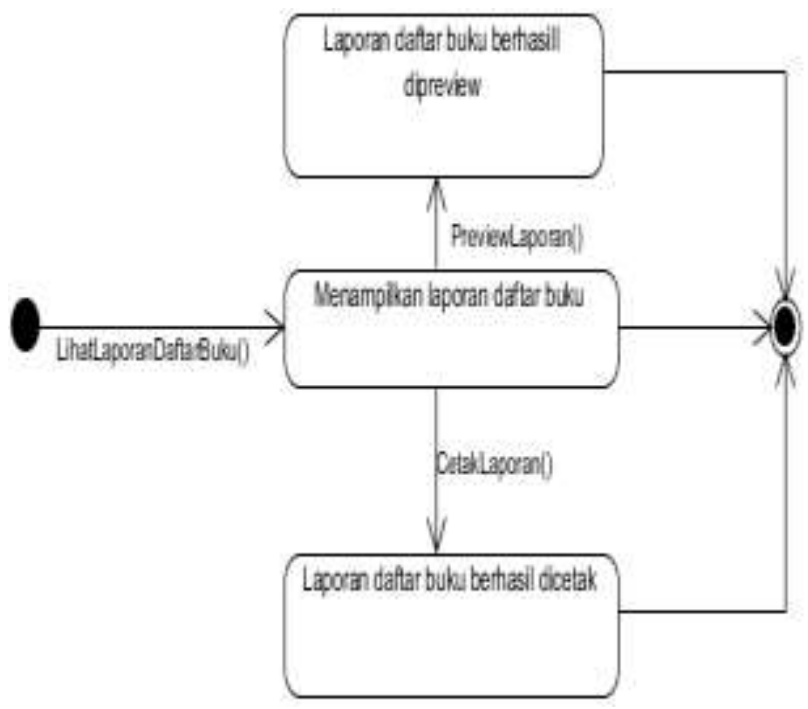

Gambar 7 State Diagram Laporan Daftar Buku

Keterangan:

Pada state diagram laporan daftar buku terdapat tiga fungsi ketika sistem mengakses objek laporan daftar buku. Fungsi tersebut memicu sistem untuk melakukan event sesuai dengan fungsi yang telah dijalankan.

Keterangan: 


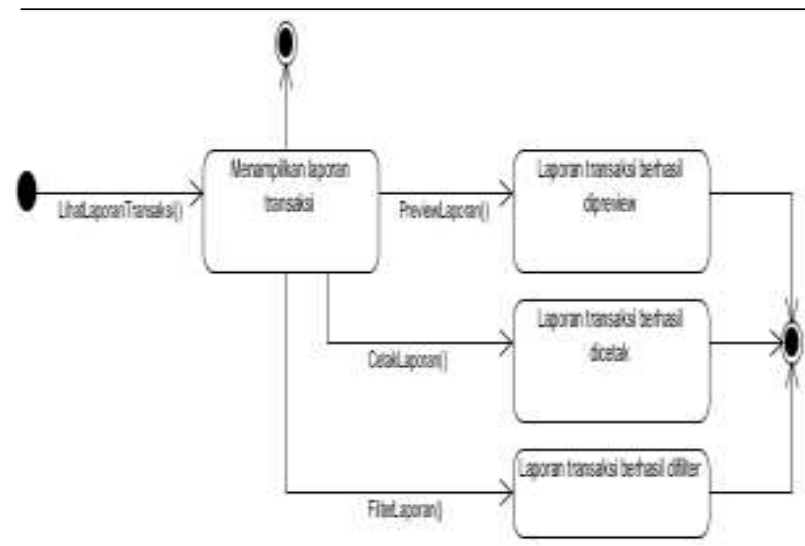

Gambar 8 State Diagram Laporan Transaksi

\section{Keterangan:}

Pada state diagram laporan transaksi terdapat empat fungsi ketika sistem mengakses objek laporan transaksi. Fungsi tersebut memicu sistem untuk melakukan event sesuai dengan fungsi yang telah dijalankan.

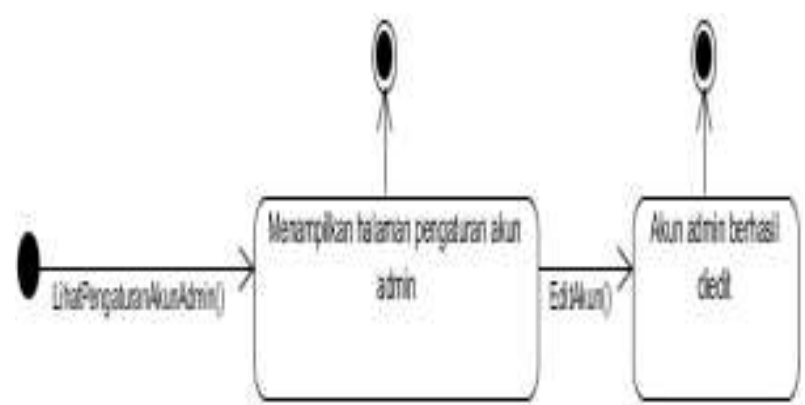

\section{Gambar 9 State Diagram Pengaturan Akun Admin}

\section{Keterangan:}

Pada state diagram pengaturan akun admin terdapat dua fungsi ketika sistem mengakses objek pengatuan akun admin. Fungsi tersebut memicu sistem untuk melakukan event sesuai dengan fungsi yang telah dijalankan.

\section{Implementasi Antarmuka}

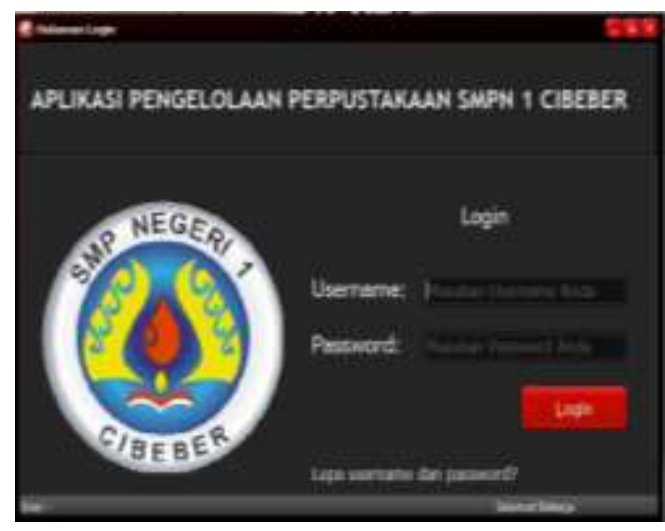

Gambar 10 Antarmuka Login

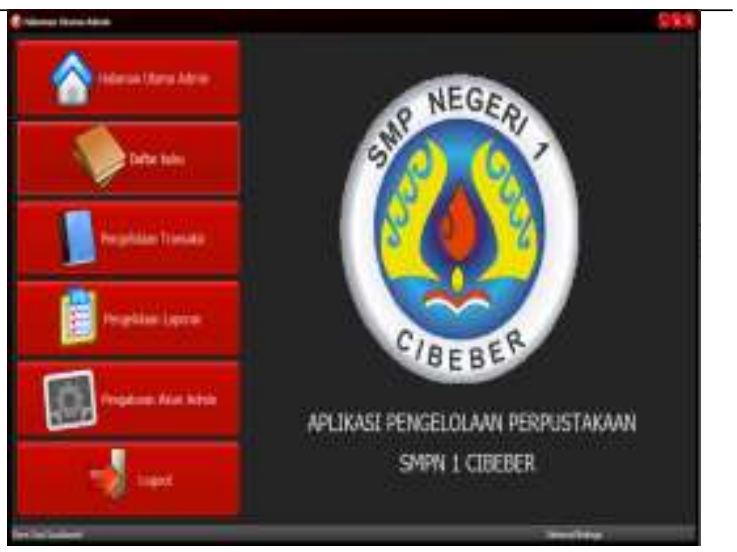

Gambar 11 Antarmuka Halaman Utama Admin

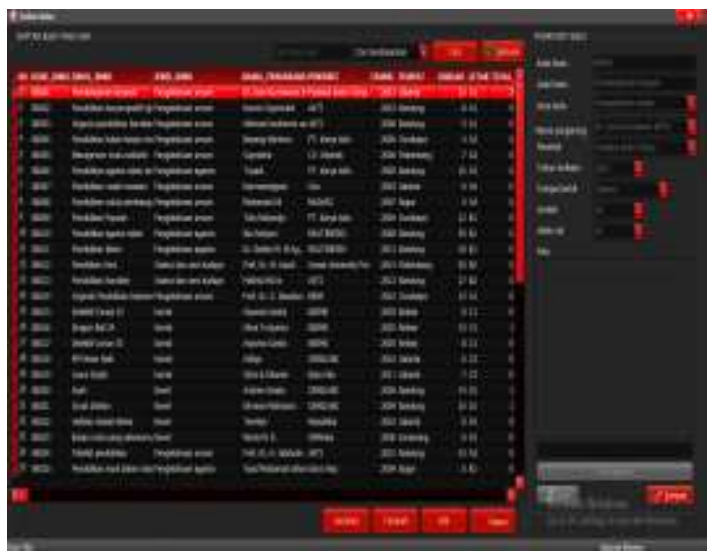

Gambar 12 Antarmuka Daftar Buku

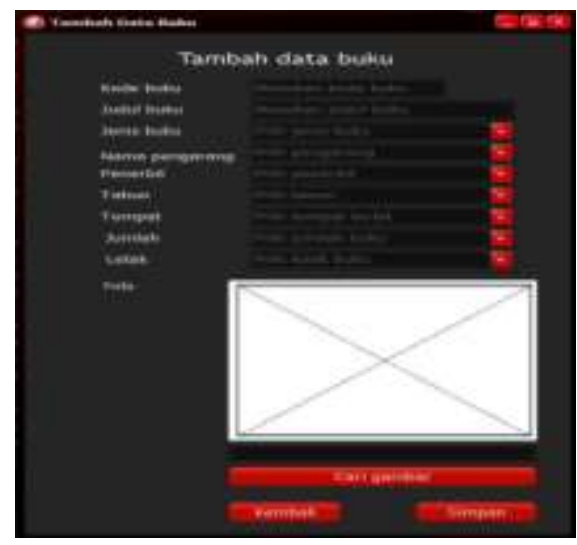

Gambar 13 Antarmuka Tambah Data Buku

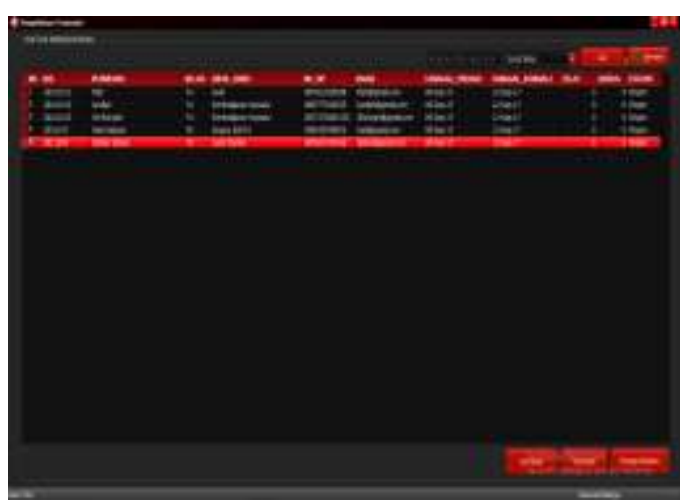

Gambar 14 Antarmuka Halaman Pengelolaan Transaksi 


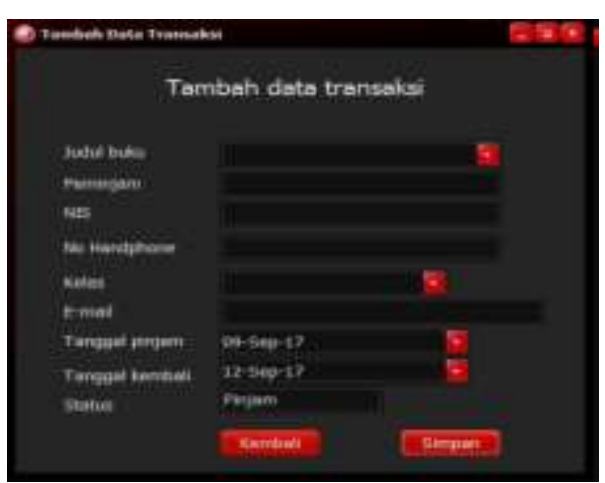

\section{Gambar 15 Antarmuka Tambah Data Transaksi}

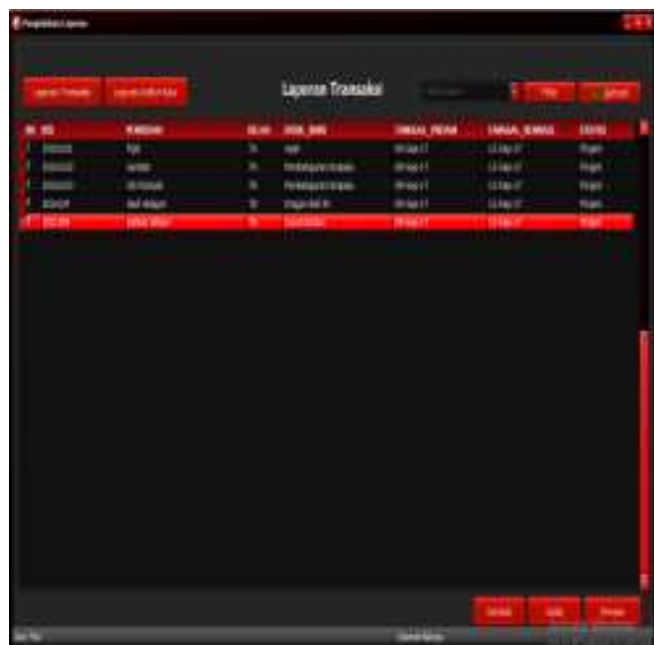

Gambar 16 Antarmuka Halaman Pengelolaan Laporan

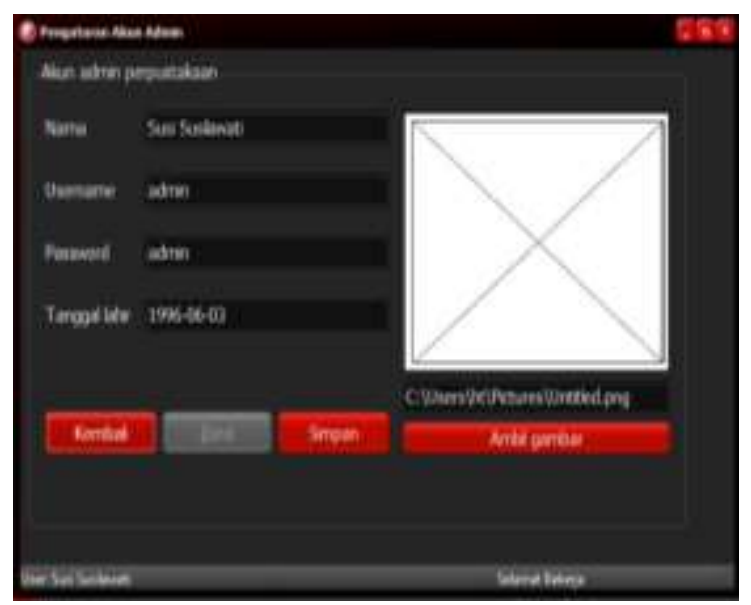

Gambar 17 Antarmuka Pengaturan Akun Admin

Metode uji coba blackbox memfokuskan pada keperluan fungsional dari software. Karena itu ujicoba blackbox memungkinkan pengembang software untuk membuat himpunan kondisi input yang akan melatih seluruh syarat-syarat fungsional suatu program. Berikut kategori kesalahan yang dapat ditemukan pada metode ini:

a. Fungsi-fungsi yang salah atau hilang

b. Kesalahan dalam struktur data atau akses database

c. Kesalahan antarmuka

d. Kesalahan inisisasi

e. Kesalahan performa

\section{Kesimpulan}

Dari hasil penelitian, perancangan dan implementasi yang telah dilakukan, penulis maka dapat disimpulkan beberapa hal sebagai berikut :

a. Aplikasi ini dapat membantu pengelola dalam proses peminjaman dan pengembalian buku perpsutakaan.

b. Aplikasi ini dapat membantu pengelola perpustakaan untuk membuat laporan daftar buku dan transaksi peminjaman.

c. Aplikasi ini dapat mempermudah pengelola untuk melakukan pengecekan keterlambatan pengembalian buku beserta jumlah sanksi yang diberikan.

\section{Daftar pustaka}

[1] Atmosudirdjo, Prajudi. 1982. Adiministrasi dan Manajemen Umum. Jakarta: Ghalia Indonesia.

[2] Hendrayudi. 2009. Pengertian Aplikasi. Yogyakarta: ANDI.

[3] Ibrahim Bafadal. 2001. Pengelolaan Perpustakaan Sekolah. Jakarta: Bumi Aksara.

[4] Jogiyanto. 1990. Analisis dan desain sistem informasi. Yogyakarta: ANDI.

[5] P. Siagian, sondng. 1997. Manajemen Sumber Daya Manusia. Jakarta: Bumi Aksara.

[6] Supriyanto.2005.Perancangan Aplikasi.Surabaya : Widyastana.

\section{Pengujian}

Pengujian merupakan bagian yang penting dalam siklus pengembangan perangkat lunak. Pengujian dilakukan untuk menjamin kualitas dan juga mengetahui kelemahan dari perangkat lunak. Tujuan dari pengujian ini adalah untuk menjamin bahwa perangkat lunak yang dibangun memiliki kualitas yang handal. Pengujian perangkat lunak ini menggunakan metode pengujian blackbox. 